\title{
Antioxidant characteristics of tea-herbal compositions
}

\section{Oleg Kuzmin, Nataliia Stukalska, Larysa Mykhonik, Olga Koval, Volodymyr Polyovyk, Ganna Berezova}

\author{
National University of Food Technologies, Kyiv, Ukraine
}

Keywords:

Herbal tea

Infusion

Antioxidant

Redox potential

Quality

Article history:

Received 21.03.2021

Received in revised

form 30.07.2021

Accepted

30.12.2021

\section{Corresponding \\ author:}

Oleg Kuzmin

E-mail:

kuzmin_ovl@ukr.net

DOI:

$10.24263 / 2304-$

974X-2021-10-4-14

\section{Abstract}

Introduction. The aim of the study was to determine the antioxidant capacity of herbal infusions and evaluate the possibility of using them to create herbal tea compositions.

Materials and methods. Antioxidant capacity of tea-herbal compositions was determined by redoxmetry and $\mathrm{pH}$-metry; sensory indicators were evaluated by expert method; results of mathematical and statistical processing were assessed by the method of linear Pearson correlation.

Results and discussion. The $\mathrm{pH}$ for water infusions from raw materials has a value of 2.35 for Hibiscus sabdariffa and 6.55 for Calamintha nepeta. The minimum theoretical value of RP $\left(E h_{m i n}\right)$ for plant water infusions was obtained, which has a value from 267.0 $\mathrm{mV}$ for Calamintha nepeta to $519.0 \mathrm{mV}$ for Hibiscus sabdariffa. The actual measured RP of infusions $\left(E h_{a c t}\right)$ was established as 37.0 $\mathrm{mV}$ for Daucus carota and $203.0 \mathrm{mV}$ for Hibiscus sabdariffa. Water infusions from vegetable raw materials have the value of regenerative capacity (recovery energy, $R E_{i n f}$ ) in the range from $R E_{\text {inf }} 150.8 \mathrm{mV}$ for Vitis vinifera) to $R E_{\text {inf }} 316.0 \mathrm{mV}$ for Hibiscus sabdariffa. For the restaurant business in the manufacture of beverages are promising water infusions of Hibiscus sabdariffa and Citrus limonum, which received increased antioxidant characteristics $R E_{\text {inf }} 316.0 \mathrm{mV}$ and $298.0 \mathrm{mV}$, respectively, and positive sensory evaluation. It is proved that the energy of reduction/oxidation of vegetable raw materials $\left(R E_{\text {plant }}\right)$ relative to the solvent - prepared water is in the range of values from $45.8 \mathrm{mV}$ for Vitis vinifera to $211.0 \mathrm{mV}$ for Hibiscus sabdariffa. Based on mathematical and statistical analysis, it was found that physicochemical parameters in the range of values with very high correlation $\left(r\right.$ 0.9-1.0) includes the following indicators: $\mathrm{pH}, E h_{\min }$, $R E_{\text {inf }}, R E_{\text {plant }}$. Rational composition of tea-herbal composition was found: Hibiscus sabdariffa, $30 \%$; Matricaria chamomilla, $20 \%$; Ilex paraguariensis, $10 \%$; Rosae fructus, $10 \%$; Mentha piperita, $10 \%$; Citrus sinensis, $8 \%$; Citrus limonum, $7 \%$; Calendulae flores, $5 \%$.

Conclusion. For the technology of the restaurant industry, the use of tea-herbal compositions from plant materials Hibiscus sabdariffa, Matricaria chamomilla, Ilex paraguariensis, Rosae fructus, Mentha piperita, Citrus sinensis, Citrus limonum, Calendulaeflores, which have increased antioxidant characteristics, is proposed. 


\section{Introduction}

\section{Characteristics of tea}

The interest of consumers in tea (Camellia sinensis) (Spizzirri et al., 2019) is explained by the fact that tea has pleasant characteristics of taste, aroma, color (Banerjee (Roy) et al. 2016; Xu et al., 2018; Zeng et al., 2017). The aroma molecules are formed mainly from precursor groups: carotenoids, fatty acids, glycosides, amino acids/sugars, volatiles ketones and alkenes (Chen et al., 2019; Feng et al., 2019; Guo et al., 2019; Li et al., 2019; Qi et al., 2018; Zhu et al., 2016). Tea aroma concentration determined by the following sequence: black $>$ white $>$ oolong $>$ dark $>$ yellow $>$ green. Black tea has the highest volatile concentration of $710 \mu \mathrm{g} / \mathrm{g}$, while green tea has the lowest concentration of $20 \mu \mathrm{g} / \mathrm{g}$ (Feng et al., 2019). Tea has a tonic effect (Długaszek et al., 2020) - to maintain the health (Hayat et al., 2015; Spizzirri et al., 2019; Vuong, 2014), normalizes metabolism, increases efficiency, eliminates fatigue (Długaszek, Kaszczuk, 2020), increases resistance to stress (Xia et al., 2020). If soft drinks lower the temperature only in the oral cavity, then tea has the ability to lower the temperature of the whole body by $1-2{ }^{\circ} \mathrm{C}$.

Tea possesses significant antioxidative, anti-inflammatory, antimicrobial, anticarcinogenic, antihypertensive, anti-cancer, neuroprotective, cholesterol-lowering, and thermogenic properties (Bekhit et al., 2011; Hayat et al., 2015; Pérez-Burillo et al., 2018; Somasundaram et al., 2019; Spizzirri et al., 2019; Vuong, 2014; Xu et al., 2018).

In teas it has been found, according to some authors 143 (Guo et al., 2019), 168 (Feng et al., 2019) and 172 (Chen et al., 2019) bioactive compounds. These ones include catechins (Pérez-Burillo et al., 2018; Somasundaram et al., 2019), polyphenols with the properties of vitamin P (Hayat et al., 2015; Pérez-Burillo et al., 2018; Spizzirri et al., 2019; Vuong, 2014), and accumulates such vitamins as ascorbic acid, thiamine, riboflavin, nicotinic, pantothenic and folic acids, carotenoids (Aboagye et al., 2021).

The tea contains antioxidants, in particular catechin, which protects the body from peroxidation - the process of self-oxidation of intracellular and tissue fat, the products of which not only reduce the function of the cell, but can also lead to its death. Tea catechins almost completely eliminate the harmful effects on the body during radioactive fallout. They have the ability to adsorb an isotope and remove it from the body before it can reach the bone marrow. Catechins also «monitor» the level of polyunsaturated fatty acids in the body, normalize cholesterol metabolism (Chen et al., 2020).

The tea leaves contain alkaloids - caffeine (Pérez-Burillo et al., 2018), theophylline, theobromine. The peculiarity of tea alkaloids is that they show their biological effect in combination with catechins and other constituents of tea. As a result, the tonic effect of tea does not cause such a sharp stimulating effect as coffee, in which the alkaloid caffeine is present in its pure form (Chen et al., 2020).

Tea is a rich source of minerals. About 20 amino acids are found in tea, and in their composition - all irreplaceable, it also contains carbohydrates, pectin substances, organic acids, resins, and essential oils (Theuma and Attard, 2020).

\section{Characteristics of herbal tea}

Herbal tea determined by the herbal components that make up the complex tea mixture. Herbal tea a mixture of black or green tea with medicinal or aromatic herbs (Coppock and Dziwenka, 2021). Tea drinks are used as substitutes for black tea in the case when there is an intolerance to the components of the tea leaf extract tannins and alkaloids such as caffeine, and theobromine because herbal tea unlike the tea, do not contain caffeine. In China, 759 species of plants are used as herbal tea (Fu et al., 2018). 
Herbal tea is a versatile drink that has a healing effect and can also be used as a preventive or therapeutic agent (Ağagündüz, 2020; Chen et al., 2019; Halim et al., 2020). Herbal tea contains a much larger amount of irreplaceable biologically active substances; constantly maintain the chemical balance of the body (Liu et al., 2020). Herbal teas increase antioxidant status (Bekhit et al., 2011; Debnath-Canning et al., 2020; Ertas, Yener, 2020; Spizzirri et al., 2019), oxidative status (Ağagündüz, 2020; Abdullah and Mazlan, 2020), anticancer activity (Morré and Morré, 2006), and has radio-protective effect (Ansari et al., 2021). Although many people drink herbal teas for pleasure, elderly people that live in rural areas often use herbal teas as affordable, accessible, and effective alternatives to medicine (Joubert et al., 2008).

Depending on the composition of raw materials and physiological effects, tea drinks are divided into groups: (a) multivitamin; regulating metabolism in the body; (b) tonic; soothing; anti-inflammatory; universal, and children's (Sviridonov et al., 2003). Most often, complex herbal compositions are used and one or more of the following components are added to the main infusion based on black (less often green) tea:

- Leaves: black currant (Liu et al., 2014), blueberry (Debnath-Canning et al., 2020), lemongrass (Aboagye et al., 2021), mint (Chan et al., 2010; Cohen et al., 2020; Somasundaram et al., 2019), nettle (Shonte et al., 2020), oregano (Chan et al., 2010), raspberry (Han et al., 2012), sea buckthorn (Ma et al., 2019), St. John's wort (Dell'Aica et al., 2007), rooibos, honeybush (Małyjurek et al., 2021), and mate (Mesquita et al., 2021);

- Flowers: hibiscus (Bekhit et al., 2011; Frész et al., 2014), cloves (Somasundaram et al., 2019), linden (Pavlović et al., 2020), calendula (Nicolaus et al., 2017), rose hip (Frész et al., 2014), and chamomile (Chaves et al., 2020);

- Fruits: apple (Bobrowska-Grzesik and Jakóbik-Kolon, 2008), apricot (Saeed et al., 2021), berberis (Atefi et al., 2021; Salehi et al, 2019), bilberry (Bobrowska-Grzesik and JakóbikKolon, 2008; Šavikin et al., 2014), black currant (Šavikin et al., 2014), chokeberry (Šavikin et al., 2014), grapes (Ansari et al., 2021; Bekhit et al., 2011; Morré, Morré, 2006), hawthorn (Dragan et al., 2012), lemon (He et al., 2018; Spizzirri et al., 2019), peach (Spizzirri et al., 2019), raspberries (Falcó et al., 2019), strawberries (Falcó et al., 2019), viburnum (Podsędek et al., 2020), and rose hip (Piljac-Žegarac et al., 2010);

- Stalks: cloudberries (Puupponen-Pimiä et al., 2016), cherries (Zhang et al., 2016), and sweet cherries (Faienza et al., 2020);

- seeds: dill (Cohen et al., 2020), caraway (Cohen et al., 2020), and coriander (Beyzi et al., 2017);

- Roots: ginger (Somasundaram et al., 2019), burdock (Maghsoumi-Norouzabad et al., 2019), and licorice (Jeon et al., 2007).

\section{Perspective directions of tea-herbal compositions}

To improve tea drinks assortment, the following ideas and suggestions are proposed:

- Use of new breeding varieties of tea plants and areas of its growth (Xu et al., 2021);

- Development of new technological solutions for tea plant processing (Dubey et al., 2020; Zohurul et al., 2020);

- Addition of leaves of various medicinal plants to tea (Baek et al., 2018; Vidović et al., 2013);

- Addition of various flavors to tea. 


\section{Relevance of the research direction}

The relevance of this topic is that the tea market is over flowing with a variety of tea drinks. Therefore, there is a need to create a qualitatively new tea-herbal composition for functional purposes.

The aim of the research is to determine the antioxidant capacity of plant raw materials infusions and evaluate their prospects for the creation of tea-herbal compositions.

To achieve the desired results, it was necessary:

(a) Confirm the feasibility of using plant materials in the creation of tea and herbal compositions.

(b) Determine the antioxidant capacity of plant materials used for the preparation of infusions.

(c) Perform mathematical and statistical analysis of antioxidant capacity of pant raw materials used in the tea-herbal compositions and to establish the internal correlation.

(d) Identify the richest sources of natural antioxidants from plant raw materials in the technology of tea-herbal compositions.

(e) Study the changes in vegetable materials in the process of blending tea and herbal compositions.

The introduction of various medicinal plants into tea makes it possible to increase the physiological activity of the original drink (Bag et al., 2022; Peng et al., 2021; Shabab et al., 2021). Since medicinal plants contain various vitamins and vitamin-like substances (Khan et al., 2021; Pohl et al., 2016), phenolic compounds (Albergaria et al., 2020), ash elements, organic acids, their introduction into tea could significantly increase the physiological value of this drink.

\section{Materials and methods}

\section{Materials}

23 samples of vegetable raw materials were used in the present study : Vitis vinifera; Calamintha nepeta; Monarda didyma; Satureja hortensis; Agastache foeniculum; Rosae fructus; Ruta graveolens; Elsholtzia stauntonii Benth; Perilla frutescens; Artemisia abrotanum; Melissae herba; Aspalathus linearis; Tiliae flos; Mentha piperita; Matricaria chamomilla; Herba Hyperici; Inonotus obliquus; Daucus carota; Ilex paraguariensis; Calendulaeflores; Citrus sinensis; Citrus limonum; Hibiscus sabdariffa. Prepared water was used as a control sample and extractant.

\section{Methods of obtaining water infusion}

Drying of vegetable raw materials was carried out to constant humidity of 6-8\%. Collected and inspected raw materials were laid out on clean white paper, each type separately. Vegetable raw materials were ground with scissors to a size of $3 \times 3 \mathrm{~mm}$, samples weighing $4 \mathrm{~g}$ were placed in $100 \mathrm{ml}$ of prepared hot water. The infusions were filtered and studies were performed to determine the indicators of active acidity, which was measured on a $\mathrm{pH}$ meter in the mode of $\mathrm{pH}$ measurement with a combined glass electrode. The RP was measured in the potential measurement mode with a combined redoxmetric platinum electrode (Kuzmin et al., 2020). 


\section{Methods for determining active acidity and $R P$}

The active acidity index was measured on a pH-meter «pH-150M» with a combined glass electrode «ESC 10601/4». RP was measured on the pH-meter «pH-150M», in the mode of measuring the potential, with a redoxmetric platinum electrode «ERP-105».

To assess the antioxidant properties of aqueous infusions of plant raw materials a method based on the difference of RP in inactivated inorganic solutions and complex biochemical media was used (Priluckij, 1997). The main criteria of this method were its clarity, simplicity, specificity, reproducibility of results and efficiency. A number of researchers also emphasize that method allows to determine the total antioxidant activity of liquid products, including in total in a complex mixture, and multifunctional antioxidants (Kuzmin et al., 2020).

Formula (1) holds for inactivated inorganic solutions in equilibrium. This formula links the active acidity of the $\mathrm{pH}$ and the RP (Priluckij, 1997):

$$
E h_{m i n}=660-60 \cdot \mathrm{pH}, \mathrm{mV}
$$

where $E h_{\min }$ is the minimum theoretically expected value of the $R P$;

$\mathrm{pH}$ is active acidity of the test solution.

Acquired meanings of $E h_{\min }$ were compared with the actual measurements of $E h_{a c t}$ of infusions. The shift of the $R P$ to the side of the recovered meanings - recovery energy $\left(R E_{i n f}\right)$ was determined by the formula (Priluckij, 1997):

$$
R E_{\text {inf }}=E h_{\text {min }}-E h_{\text {act }}, \mathrm{mV}
$$

where $R E_{i n f}$ is the shift of the RP to the side of recovered meanings;

$E h_{a c t}$ is actual measured of the $R P$.

The energy of reduction/oxidation of vegetable raw materials $\left(R E_{\text {plant }}\right)$ is determined by the difference between the $R P$ of infusions of vegetable raw materials $\left(R E_{\text {inf }}\right)$ and solvent $\left(R E_{s o l}\right)$ (control is prepared water) (Kuzmin et al., 2020):

$$
R E_{\text {plant }}=R E_{\text {inf }}-R E_{\text {sol }}, \mathrm{mV}
$$

Based on the research results, an improved method for assessing the antioxidant capacity of herbal infusions for creating tea-herbal compositions has been developed.

\section{Expert method of sensory evaluation}

The expert method of values quality indexes determination is based on committing the thought of the highly skilled and experienced specialists-experts (Kuzmin et al., 2020).

\section{Mathematical and statistical methods}

Pearson correlation coefficient measures the strength of the linear association between variables. Each variable should be continuous, random sample and approximately normally distributed. There are many rules of thumb on how to interpret a correlation coefficient, but all of them are domain specific. For example, here is correlation coefficient (Table 1) interpretation for behavioral sciences offered by Hinkle et al., 2003. 
Correlation coefficient interpretation

\begin{tabular}{|c|c|}
\hline Absolute value of coefficient $(\boldsymbol{r})$ & Strength of correlation \\
\hline $0.90-1.00$ & Very high \\
\hline $0.70-0.90$ & High \\
\hline $0.50-0.70$ & Moderate \\
\hline $0.30-0.50$ & Low \\
\hline $0.00-0.30$ & Little, if any \\
\hline
\end{tabular}

The correlation coefficient can take a range of values from +1 to -1 . Positive correlation coefficient means that if one variable gets bigger, the other variable also gets bigger, so they tend to move in the same direction. Negative correlation coefficient means that the variables tend to move in the opposite directions: If one variable increases, the other variable decreases, and vice-versa. When correlation coefficient is close to zero two variables have no linear relationship (Hinkle et al., 2003; Shendrik et al., 2019).

\section{Results and discussions}

\section{Results of antioxidant capacity}

Physicochemical studies, namely determination of the $p H$ level and $R P$ (Nicoli et al., 2004; Prévost, Brillet-Viel, 2014), were performed according to the method (Priluckij, 1997) and calculations given above (Kuzmin et al., 2020). As a result of extraction received infusions (Andreou et al., 2018), physicochemical indicators (Breiter et al., 2011) of which are presented in the Table 2. As a solvent used a prepared water: $p H 8.00$ units $\mathrm{pH} ; E h_{\text {min }}$ $180.0 \mathrm{mV} ; E h_{\text {act }} 75.0 \mathrm{mV} ; R E_{\text {inf }} 105.0 \mathrm{mV}$.

Figures 1-5 show graphically the change in the physicochemical indicators of the quality of extracts of raw materials on the extractant.

The $p H$ for water infusions from raw materials (Figure 1) has a value of 2.35 units $p H$ (Hibiscus sabdariffa) to 6.55 units $\mathrm{pH}$ (Calamintha nepeta).

The minimum theoretical value of $R P\left(E h_{\min }\right)$ for plant water infusions (Priluckij, 1997) was obtained, which has a value from $267.0 \mathrm{mV}$ (Calamintha nepeta) to $519.0 \mathrm{mV}$ (Hibiscus sabdariffa) (Figure 2).

The actual measured $R P$ of infusions $\left(E h_{a c t}\right)$ was established - from $37.0 \mathrm{mV}$ (Daucus carota) to $203.0 \mathrm{mV}$ (Hibiscus sabdariffa) (Figure 3). 
Table 2

Quality indicators of extracts on extractant

\begin{tabular}{|c|c|c|c|c|c|}
\hline Plant raw materials & $\underset{\text { pH }}{p H, \text { units }}$ & $\begin{array}{c}E h_{\min }, \\
\mathrm{mV}\end{array}$ & $\begin{array}{c}\text { Eh }{ }_{\text {act }}, \\
\mathbf{m V}\end{array}$ & $\begin{array}{c}R E_{i n f}, \\
\mathrm{mV}\end{array}$ & $\begin{array}{c}R E_{\text {plant }} \\
\mathrm{mV}\end{array}$ \\
\hline 1. Extractant-prepared water & 8.00 & 180.0 & 75.0 & 105.0 & 0.0 \\
\hline 2. Vitis vinifera & 6.47 & 271.8 & 121.0 & 150.8 & 45.8 \\
\hline 3. Calamintha nepeta & 6.55 & 267.0 & 94.0 & 173.0 & 68.0 \\
\hline 4. Monarda didyma & 6.39 & 276.6 & 102.0 & 174.6 & 69.6 \\
\hline 5. Satureja hortensis & 6.48 & 271.2 & 96.0 & 175.2 & 70.2 \\
\hline 6. Agastache foeniculum & 6.32 & 280.8 & 95.0 & 185.8 & 80.8 \\
\hline 7. Rosae fructus & 6.11 & 293.4 & 107.0 & 186.4 & 81.4 \\
\hline 8. Ruta graveolens & 6.07 & 295.8 & 108.0 & 187.8 & 82.8 \\
\hline 9. Elsholtzia stauntonii Benth & 6.48 & 271.2 & 80.0 & 191.2 & 86.2 \\
\hline 10. Perilla frutescens & 6.24 & 285.6 & 93.0 & 192.6 & 87.6 \\
\hline 11. Artemisia abrotanum & 6.23 & 286.2 & 89.0 & 197.2 & 92.2 \\
\hline 12. Melissae herba & 6.18 & 289.2 & 90.0 & 199.2 & 94.2 \\
\hline 13. Aspalathus linearis & 6.00 & 300.0 & 95.0 & 205.0 & 100.0 \\
\hline 14. Tiliae flos & 6.31 & 281.4 & 76.0 & 205.4 & 100.4 \\
\hline 15. Mentha piperita & 6.01 & 300.0 & 86.0 & 214.0 & 109.0 \\
\hline 16. Matricaria chamomilla & 5.58 & 325.2 & 105.0 & 220.2 & 115.2 \\
\hline 17. Herba Hyperici & 5.00 & 360.0 & 132.0 & 228.0 & 123.0 \\
\hline 18. Inonotus obliquus & 5.40 & 336.0 & 97.0 & 239.0 & 134.0 \\
\hline 19. Daucus carota & 6.39 & 276.6 & 37.0 & 239.6 & 134.6 \\
\hline 20. Ilex paraguariensis & 5.87 & 307.8 & 57.0 & 250.8 & 145.8 \\
\hline 21. Calendulae flores & 5.55 & 327.0 & 63.0 & 264.0 & 159.0 \\
\hline 22. Citrus sinensis & 5.18 & 349.2 & 54.0 & 295.2 & 190.2 \\
\hline 23. Citrus limonum & 4.85 & 369.0 & 71.0 & 298.0 & 193.0 \\
\hline 24. Hibiscus sabdariffa & 2.35 & 519.0 & 203.0 & 316.0 & 211.0 \\
\hline $\min$ & 2.35 & 267.0 & 37.0 & 150.8 & 45.8 \\
\hline $\max$ & 6.55 & 519.0 & 203.0 & 316.0 & 211.0 \\
\hline
\end{tabular}

where: $p H$ - active acidity of the test solution; $E h_{\min }$ - the minimum theoretically expected value of the $R P ; E h_{a c t}$-actual measured of the $R P ; R E_{\text {inf }}$ - the shift of the $R P$ to the side of recovered meanings; $R E_{\text {plant }}$ - the energy of reduction/oxidation of vegetable raw materials

Water infusions from vegetable raw materials have the value of regenerative capacity (recovery energy $-R E_{i n f}$ ) in the range from $R E_{\text {inf }}-150.8 \mathrm{mV}$ (Vitis vinifera) to $R E_{\text {inf }}-316.0$ $\mathrm{mV}$ (Hibiscus sabdariffa).

For the restaurant business in the manufacture of beverages are promising water infusions of Hibiscus sabdariffa and Citrus limonum, which received increased antioxidant characteristics $R E_{\text {inf }}-316.0 \mathrm{mV}$ and $R E_{\text {inf }}-298.0 \mathrm{mV}$, respectively (Figure 4), and positive sensory evaluation. 


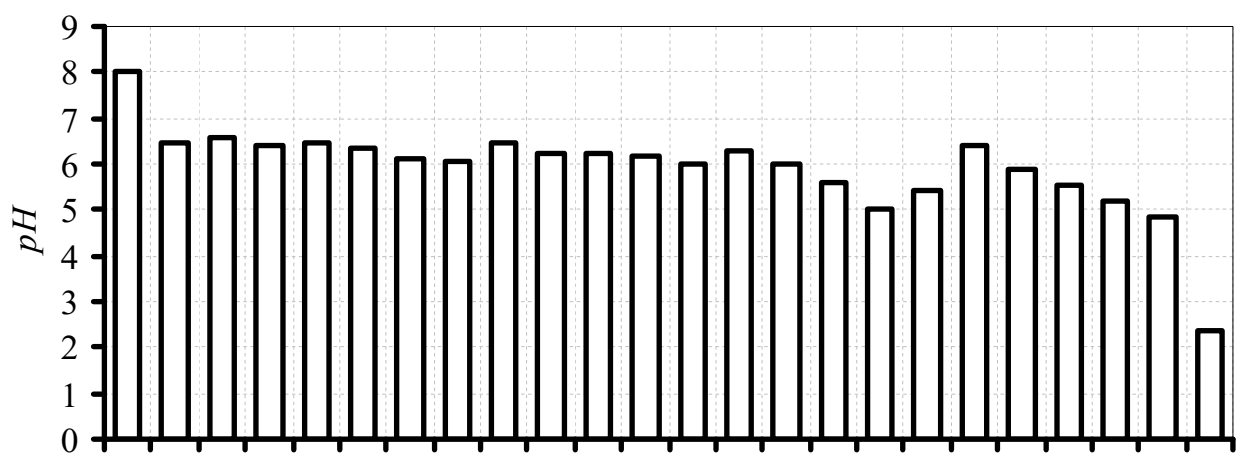

$\begin{array}{llllllllllllllllllllllll}1 & 2 & 3 & 4 & 5 & 6 & 7 & 8 & 9 & 10 & 11 & 12 & 13 & 14 & 15 & 16 & 17 & 18 & 19 & 20 & 21 & 22 & 23 & 24\end{array}$

Figure 1. Hydrogen index $(\mathrm{pH})$ of infusions of the investigated raw material:

1 -Extractant; 2 - Vitis vinifera; 3 - Calamintha nepeta; 4 - Monarda didyma;

5 - Satureja hortensis; 6-Agastache foeniculum; 7 -Rosae fructus; 8 -Ruta graveolens;

9 - Elsholtzia stauntonii Benth; 10 - Perilla frutescens; 11 - Artemisia abrotanum;

12 -Melissae herba; 13 - Aspalathus linearis; 14 -Tiliae flos; 15 -Mentha piperita;

16-Matricaria chamomilla; 17 - Herba Hyperici; 18 - Inonotus obliquus; 19 -Daucus carota;

20 - Ilex paraguariensis; 21 - Calendulaeflores; 22 -Citrus sinensis; 23 - Citrus limonum; 24 - Hibiscus sabdariffa

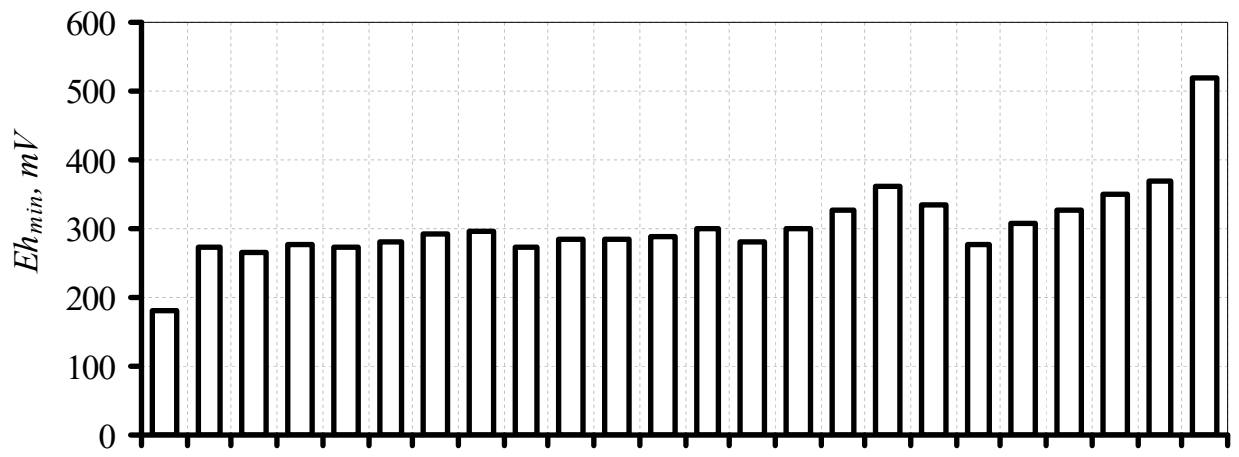

$1 \quad 2 \quad 3 \quad 4 \quad 5 \quad 6 \quad 7 \quad 8 \quad 9 \quad 1011 \quad 12131415161718192021222324$

Figure 2. Minimum theoretical value of $R P\left(E h_{\min }\right)$ of infusions of the investigated raw material:

1 -Extractant; 2 - Vitis vinifera; 3 - Calamintha nepeta; 4 -Monarda didyma;

5 -Satureja hortensis; 6-Agastache foeniculum; 7 -Rosae fructus; 8 -Ruta graveolens;

9 - Elsholtzia stauntonii Benth; 10 - Perilla frutescens; 11 - Artemisia abrotanum;

12 -Melissae herba; 13 -Aspalathus linearis; 14 -Tiliae flos; 15 -Mentha piperita;

16 - Matricaria chamomilla; 17 - Herba Hyperici; 18 -Inonotus obliquus; 19 - Daucus carota;

20 - Ilex paraguariensis; 21 - Calendulae flores; 22 -Citrus sinensis; 23 -Citrus limonum; 24 - Hibiscus sabdariffa 


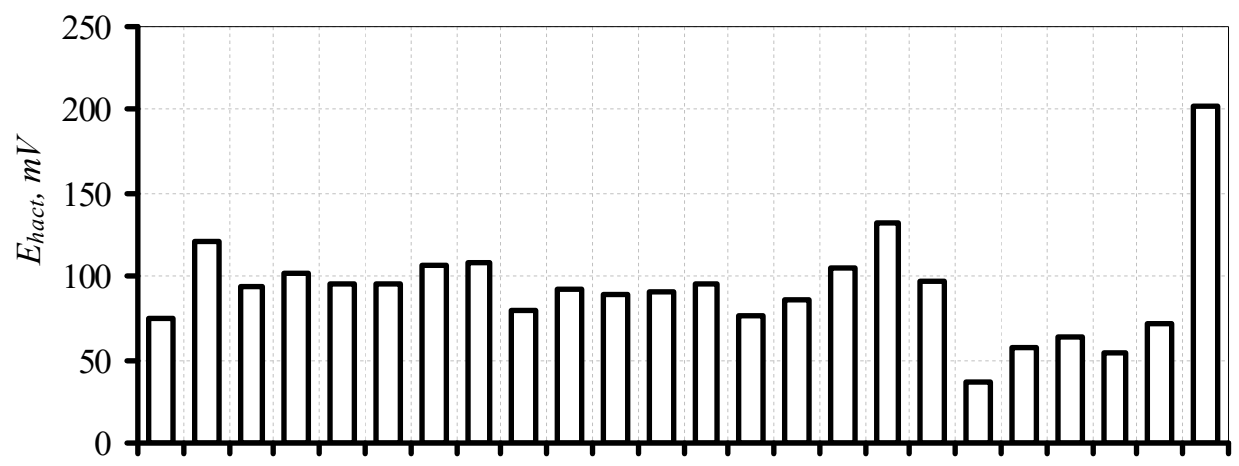

$1 \quad 2 \quad 3 \quad 4 \quad 5 \quad 6 \quad 7 \quad 8 \quad 9 \quad 1011 \quad 12131415161718192021222324$

Figure 3. Actual measured $R P$ of infusions $\left(E h_{a c t}\right)$ of the investigated raw material: 1 -Extractant; 2 - Vitis vinifera; 3 - Calamintha nepeta; 4-Monarda didyma;

5 -Satureja hortensis; 6-Agastache foeniculum; 7 -Rosae fructus; 8-Ruta graveolens;

9 - Elsholtzia stauntonii Benth; 10 - Perilla frutescens; 11 - Artemisia abrotanum;

12 -Melissae herba; 13 - Aspalathus linearis; 14 -Tiliae flos; 15 -Mentha piperita;

16 - Matricaria chamomilla; 17 - Herba Hyperici; 18 -Inonotus obliquus; 19 -Daucus carota;

20 - Ilex paraguariensis; 21 - Calendulae flores; 22 -Citrus sinensis; 23 -Citrus limonum;

24 - Hibiscus sabdariffa

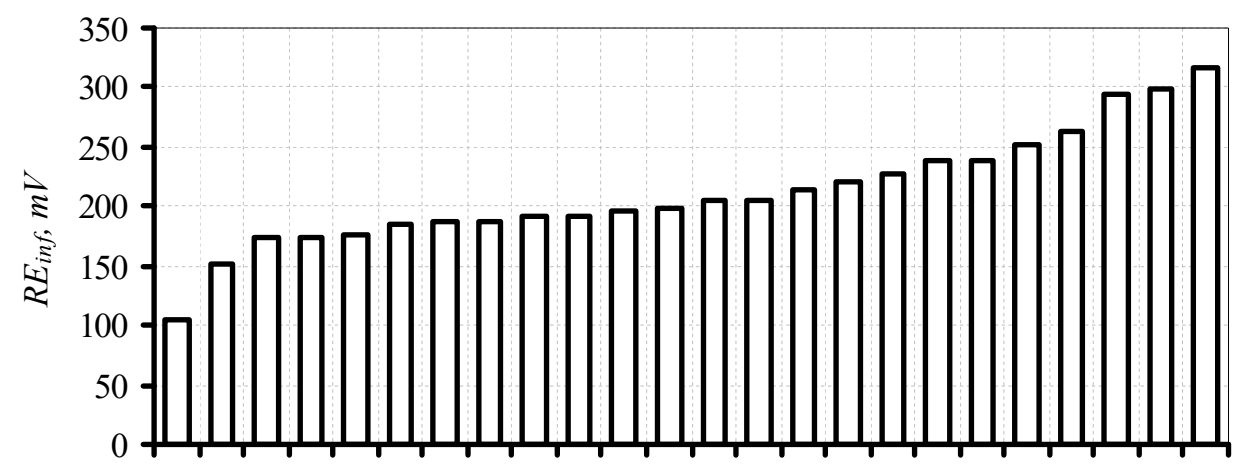

$\begin{array}{llllllllllllllllllllllll}1 & 2 & 3 & 4 & 5 & 6 & 7 & 8 & 9 & 10 & 11 & 12 & 13 & 14 & 15 & 16 & 17 & 18 & 19 & 20 & 21 & 22 & 23 & 24\end{array}$

Figure 4. Recovery energy $\left(R E_{i n f}\right)$ of infusions of the investigated raw material:

1 -Extractant; 2 - Vitis vinifera; 3 - Calamintha nepeta; 4 -Monarda didyma;

5 -Satureja hortensis; 6-Agastache foeniculum; 7 -Rosae fructus; 8 -Ruta graveolens;

9 - Elsholtzia stauntonii Benth; 10 - Perilla frutescens; 11 - Artemisia abrotanum;

12 -Melissae herba; 13 - Aspalathus linearis; 14 -Tiliae flos; 15 -Mentha piperita;

16 - Matricaria chamomilla; 17 - Herba Hyperici; 18 - Inonotus obliquus; 19 -Daucus carota;

20 - Ilex paraguariensis; 21 - Calendulae flores; 22 - Citrus sinensis; 23 - Citrus limonum; 24 - Hibiscus sabdariffa

It is proved that the energy of reduction/oxidation of vegetable raw materials $\left(R E_{\text {plant }}\right)$

— Ukrainian Food Journal. 2021. Volume 10. Issue 4 — 815 
relative to the solvent - prepared water is in the range of values from $45.8 \mathrm{mV}$ (Vitis vinifera) to $211.0 \mathrm{mV}$ (Hibiscus sabdariffa) (Figure 5). It was found that water infusions, depending on the activity of plant raw materials have a reducing capacity (over $0 \mathrm{mV}$ ) $-100 \%$ of samples.

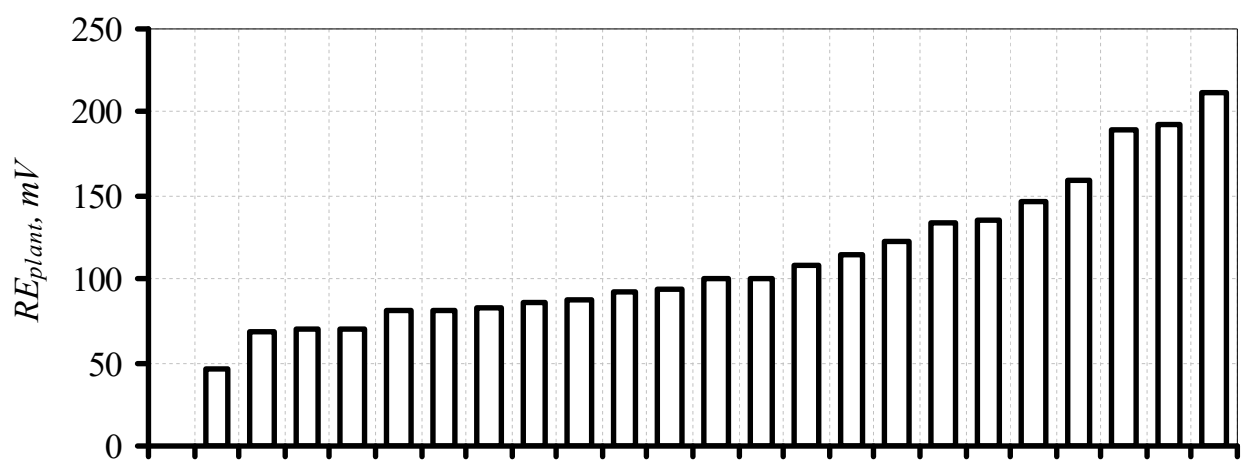

$1 \quad 2 \quad 3 \quad 4 \quad 5 \quad 6 \quad 7 \quad 8 \quad 9 \quad 101112131415161718192021222324$

Figure 5. Energy of reduction/oxidation of vegetable raw materials $\left(R E_{\text {plant }}\right)$ : 1 - Extractant; 2 - Vitis vinifera; 3 - Calamintha nepeta; 4-Monarda didyma;

5 - Satureja hortensis; 6 -Agastache foeniculum; 7 -Rosae fructus; 8-Ruta graveolens;

9 - Elsholtzia stauntonii Benth; 10 - Perilla frutescens; 11 -Artemisia abrotanum;

12 - Melissae herba; 13 - Aspalathus linearis; 14 -Tiliae flos; 15-Mentha piperita;

16 - Matricaria chamomilla; 17 - Herba Hyperici; 18 -Inonotus obliquus; 19 - Daucus carota;

20 - Ilex paraguariensis; 21 -Calendulae flores; 22 - Citrus sinensis; 23 - Citrus limonum; 24 - Hibiscus sabdariffa

\section{Determination of Pearson's linear correlation}

According to the physicochemical and sensory evaluation, mathematical and statistical analysis (Hinkle et al., 2003; Shendrik et al., 2019) was performed in the Pearson correlation matrix (Table 3).

Table 3

Marked correlations $(r)$ are significant at $p<0,05 ; N=24$

\begin{tabular}{|l|c|c|c|c|c|}
\hline & $\boldsymbol{p H}$ & $\boldsymbol{E \boldsymbol { h } _ { \text { min } }}$ & $\boldsymbol{E h}_{\text {act }}$ & $\boldsymbol{R} \boldsymbol{E}_{\text {inf }}$ & $\boldsymbol{R E}_{\text {plant }}$ \\
\hline$p H$ & & $\mathbf{- 1 . 0 0}$ & -0.58 & -0.85 & -0.85 \\
\hline$E h_{\min }$ & $-\mathbf{- 1 . 0 0}$ & & 0.58 & 0.85 & 0.85 \\
\hline$E h_{\text {act }}$ & -0.58 & 0.58 & & 0.06 & 0.06 \\
\hline$R E_{\text {inf }}$ & -0.85 & 0.85 & 0.06 & & $\mathbf{1 . 0 0}$ \\
\hline$R E_{\text {plant }}$ & -0.85 & 0.85 & 0.06 & $\mathbf{1 . 0 0}$ & \\
\hline
\end{tabular}

where: $p H$-active acidity of the test solution; $E h_{\min }$ - the minimum theoretically expected value of the $R P ; E h_{\text {act }}$ - actual measured of the $R P ; R E_{\text {inf }}$ - the shift of the $R P$ to the side of recovered meanings; $R E_{\text {plant }}$ - the energy of reduction/oxidation of vegetable raw materials

According to the obtained matrix $5 * 5$, it was found that of the 5 indicators $\left(p H, E h_{\text {min }}\right.$, $E h_{a c t}, R E_{\text {inf }}, R E_{\text {plant }}$ ) in the range of values with very high correlation (r 0.9-1.0) includes the following indicators: $p H, E h_{\min }, R E_{\text {inf }}, R E_{p l a n t}$. 
Figure 6 shows the graphical dependence of $p H$ on $E h_{\text {min }}$. It was found that the $p H$ is in the range of 2.35-8.00, and $E h_{\min }-519.0-180.0 \mathrm{mV}$. According to the obtained equation, at a $p H$ value of $6.00 E h_{\min }$ is $300 \mathrm{mV}$. When the $p H$ value changes by 1 ( $\left.p H 5.00\right)$, the $E h_{\text {min }}$ increases by $60 \mathrm{mV}\left(E h_{\min } 360 \mathrm{mV}\right)$. That is, the relationship between $E h_{\text {min }}$ and $p H$ is very high, because $r=-1$, because it is inversely correlated, which leads to an increase in $p H$ to a decrease in the level of $E h_{\text {min }}$.

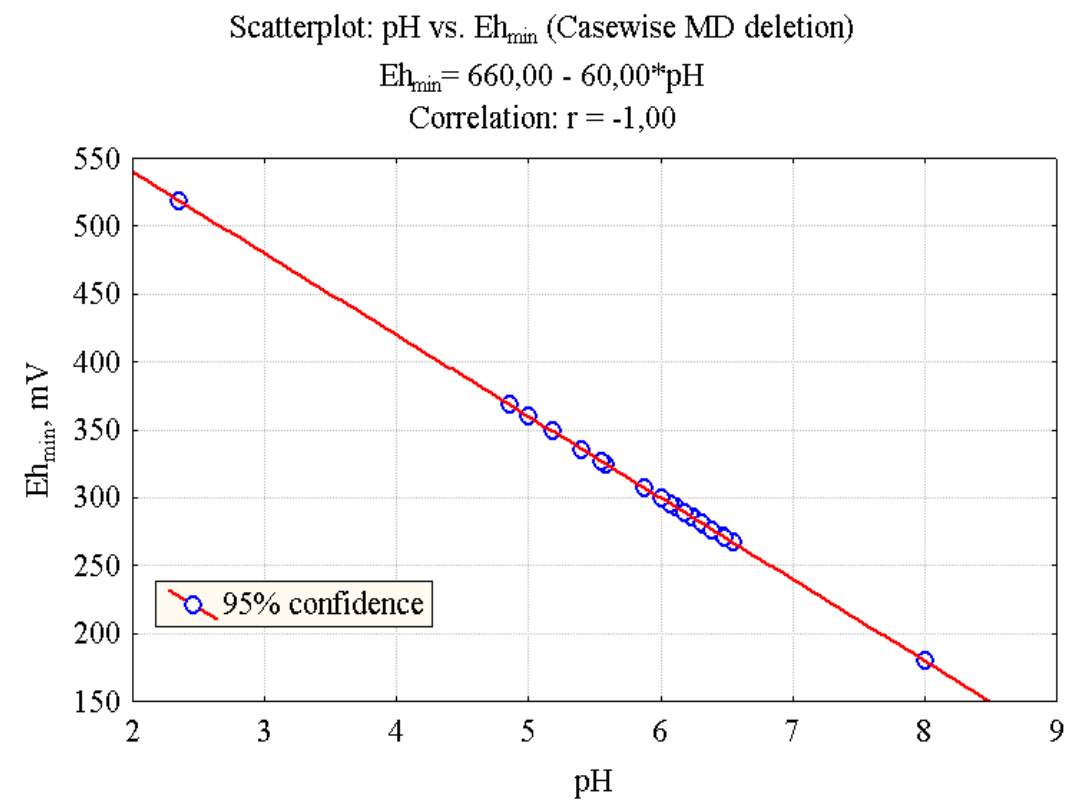

Figure 6. Dependence of $\mathrm{pH}$ level on $E \boldsymbol{h}_{\min }$

Figures 7-11 show the graphical dependence of the $p H$ level, $E h_{\min }, R E_{\text {inf }}, R E_{\text {plant }}$.

It was found that $R E_{i n f}$, is in the range from 105 to $316 \mathrm{mV}$, and the $p H$ is $8.00-2.35$. At the value of $R E_{\text {inf }} 205 \mathrm{mV}$, the $p H$ level is 6.0. If you reduce the $p H$ to by one to 5.0 then the value of $R E_{\text {inf }}$ will be $228 \mathrm{mV}$, i.e. $R E_{\text {inf }}$ will increase by $23 \mathrm{mV}$. This is due to the fact that there is a high interdependence between the variables $R E_{\text {inf }}$ and $p H(r=-0.85)$. As the $p H$ value increases, the $R E_{\text {inf }}$ index decreases (Figure 7).

It was found that $R E_{\text {plant }}$ is in the range from 0.0 to $211.0 \mathrm{mV}$, and the $p H$ is $8.00-2.35$. When the value of $R E_{\text {plant }} 100.0 \mathrm{mV}$, the $p H$ level is 6.0 . If you reduce the $p H$ by one to 5.0, the value of $R E_{\text {plant }}$ will be $123.0 \mathrm{mV}$. Decreasing the $p H$ per unit from 6.0 to 5.0 leads to a decrease in $R E_{\text {plant }}$ by $23 \mathrm{mV}$. This is due to the fact that there is a high interdependence between the variables $R E_{\text {plant }}$ and $p H(r=-0.85)$. As the $p H$ value increases, the $R E$ decreases (Figure 8).

Figure 11 shows the graphical dependence of $R E_{\text {plant }}$ on $R E_{\text {inf }}$. It was found that the $R E_{\text {plant }}$ is in the range of 0.0 to $211.0 \mathrm{mV}$, and $R E_{\text {inf }}-105$ to $316 \mathrm{mV}$. According to the obtained equation, at a $R E_{\text {plant }}$ value of $100 \mathrm{mV} R E_{\text {inf }}$ is $205 \mathrm{mV}$. When the $R E_{\text {plant }}$ value changes by 1 $\left(R E_{\text {plant }} 101 \mathrm{mV}\right)$, the $R E_{\text {inf }}$ decreases by $105 \mathrm{mV}\left(R E_{\text {inf }} 206 \mathrm{mV}\right)$. That is, the relationship between $R E_{\text {plant }}$ and $R E_{\text {inf }}$ is very high, because $r=1$, because it is directly correlated, which leads to an increase in $R E_{\text {plant }}$ to a increase in the level of $R E_{\text {inf. }}$. 


\section{- Food Technology —}

Scatterplot: $\mathrm{pH}$ vs. $\mathrm{RE}_{\text {inf }}$ (Casewise $\mathrm{MD}$ deletion)

$$
\mathrm{RE}_{\text {inf }}=456,57-41,29 * \mathrm{pH}
$$

Correlation: $r=-0,85$

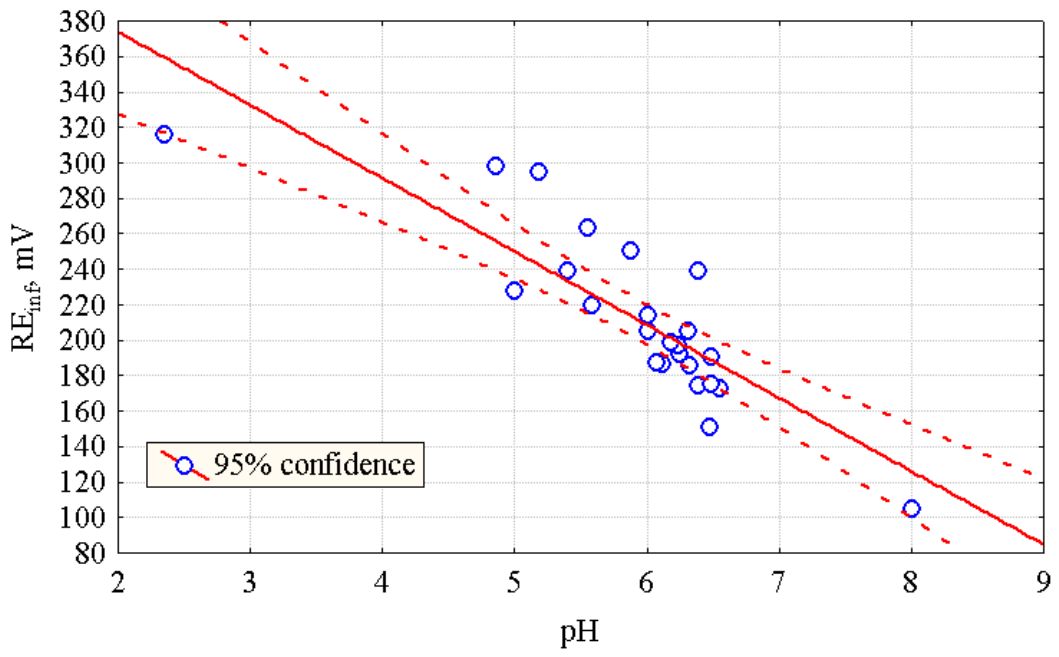

Figure 7. Dependence of $p H$ level on $R E_{i n f}$

Scatterplot: $\mathrm{pH}$ vs. $\mathrm{RE}_{\text {plant }}$ (Casewise MD deletion)

$$
\mathrm{RE}_{\mathrm{plant}}=351,57-41,29 * \mathrm{pH}
$$

Correlation: $r=-0,85$

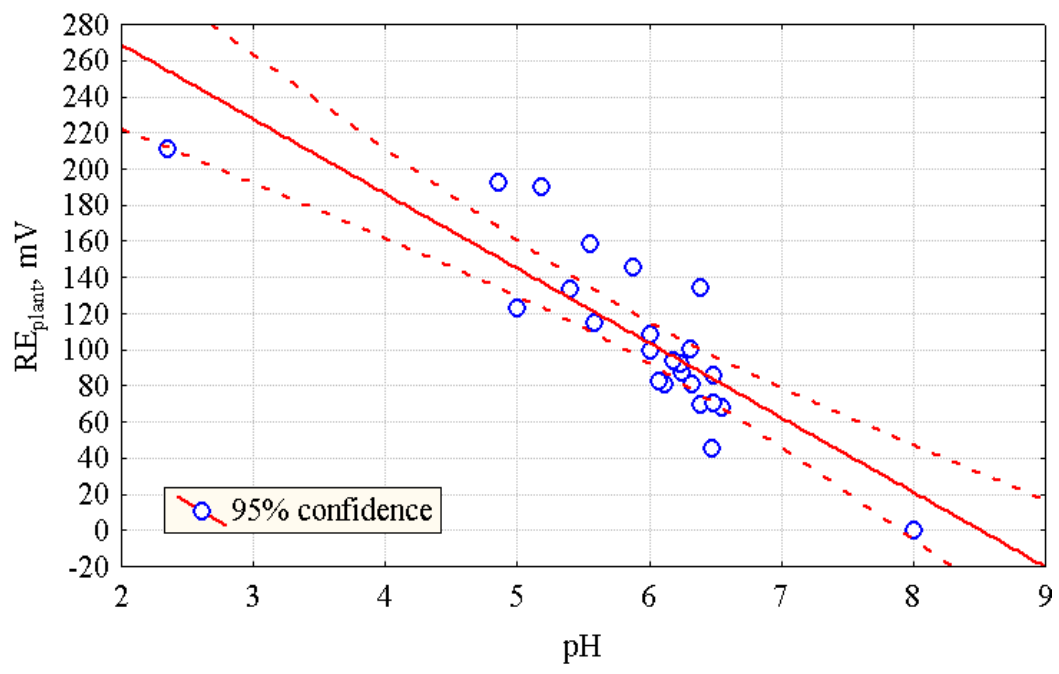

Figure 8. Dependence of $p H$ level on $R E_{p l a n t}$ 
Scatterplot: $\mathrm{Eh}_{\min }$ vs. $\mathrm{RE}_{\text {inf }}$ (Casewise $\mathrm{MD}$ deletion)

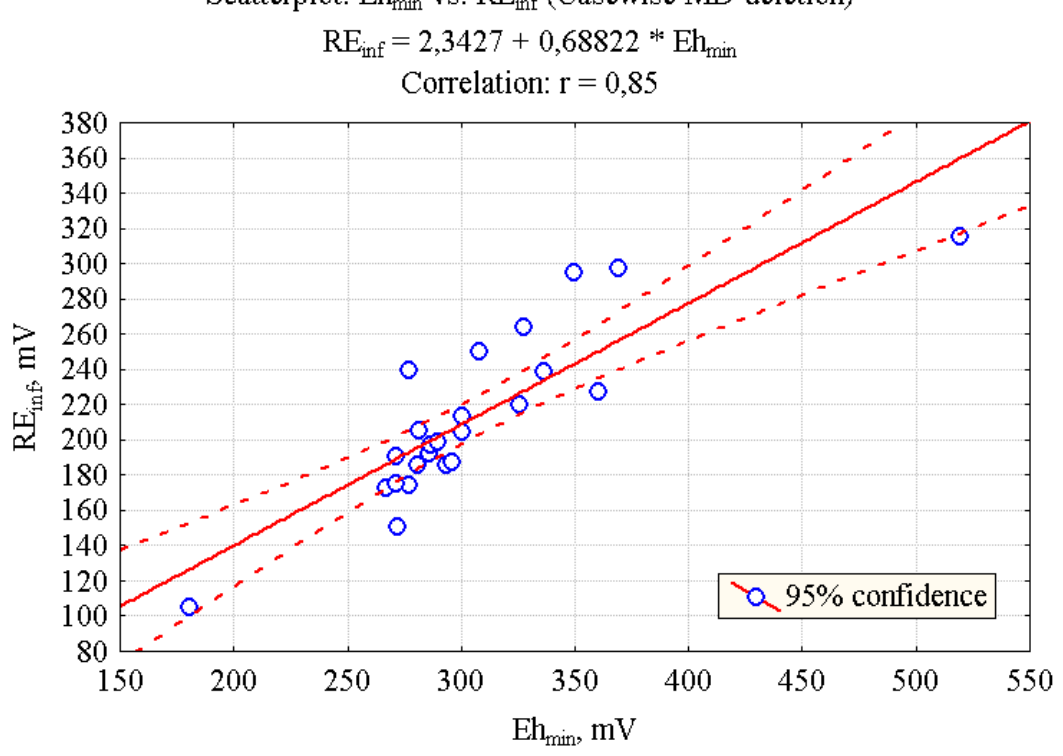

Figure 9. Dependence of $E h_{\min }$ on $R E_{\text {inf }}$

Scatterplot: $\mathrm{Eh}_{\min }$ vs. $\mathrm{RE}_{\text {plant }}$ (Casewise $\mathrm{MD}$ deletion)

$$
\mathrm{RE}_{\text {plant }}=-102,7+0,68822 * \mathrm{Eh}_{\text {min }}
$$

Correlation: $r=0,85$

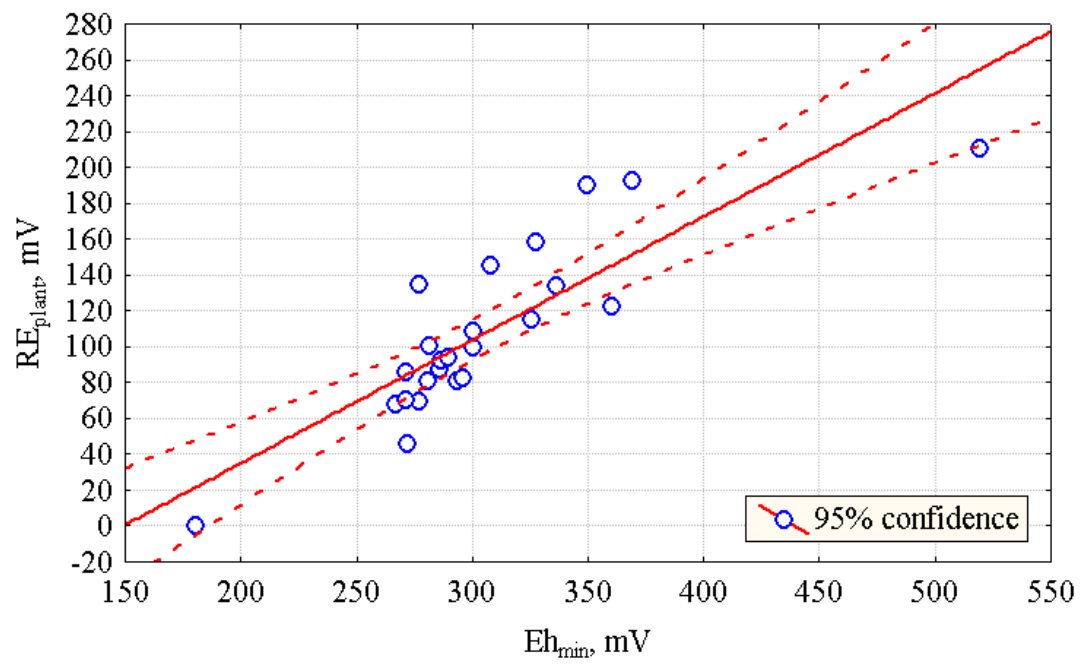

Figure 10. Dependence of $E h_{\min }$ on $R E_{p l a n t}$ 


\section{-Food Technology —}

Scatterplot: $\mathrm{RE}_{\text {plant }}$ vs. $\mathrm{RE}_{\text {inf }}$ (Casewise $\mathrm{MD}$ deletion)

$$
\begin{aligned}
\mathrm{RE}_{\text {inf }}= & 105,00+1,0000^{*} \mathrm{RE}_{\text {plant }} \\
& \text { Correlation: } \mathrm{r}=1,00
\end{aligned}
$$

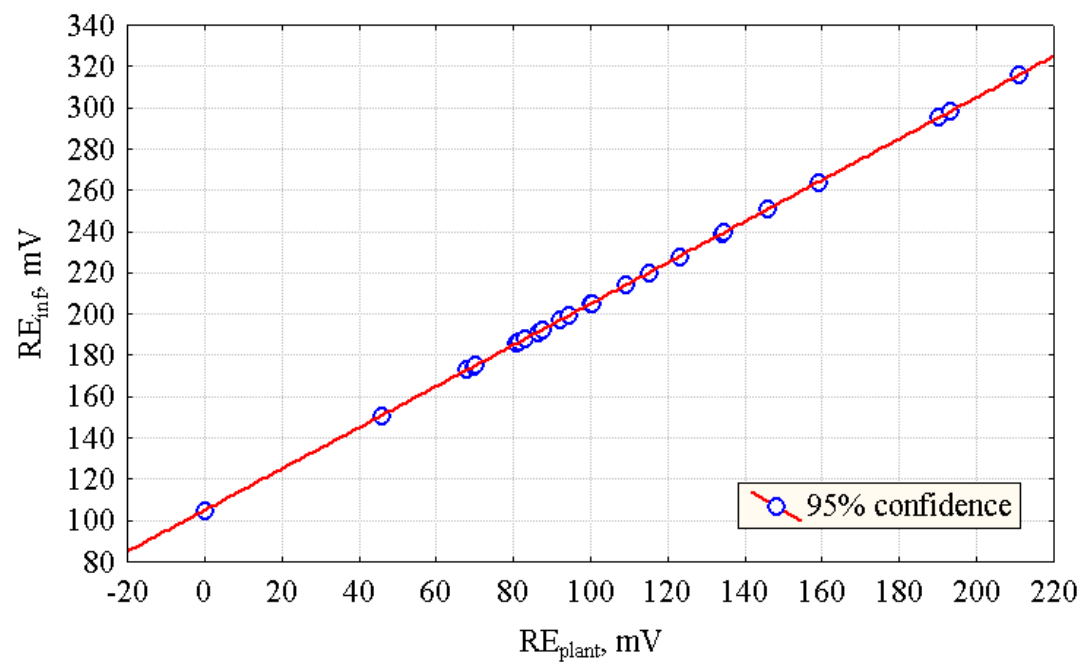

Figure 11. Dependence of $R E_{\text {plant }}$ on $R E_{\text {inf }}$

The general graph of the three most correlation-significant physicochemical parameters is shown in Figure 12. In volumetric form, it is seen that some points $\left(E h_{\min }, R E_{\text {plant }}, R E_{\text {inf }}\right)$ are as close as possible to the surface, i.e. there is a very strong correlation between them. The farther the points are from the surface, the weaker the relationship.

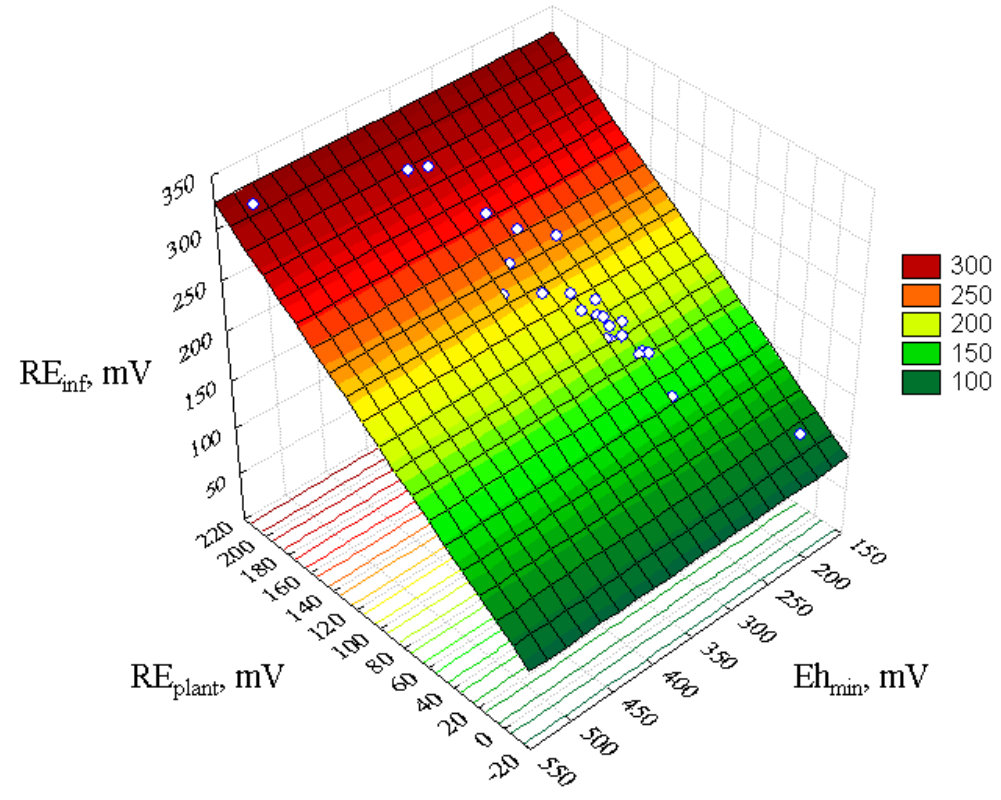

Figure 12. Response surface of $E h_{\text {min }}$ from $R E_{\text {plant }}$ and $R E_{\text {inf }}$ 
Based on mathematical and statistical analysis, it was found that physicochemical parameters in the range of values with very high correlation $(r 0.9-1.0)$ includes the following indicators: $p H, E h_{\text {min }}, R E_{\text {inf }}, R E_{\text {plant }}$.

\section{Creation of tea-herbal compositions}

The prospects of creating tea-herbal compositions based on ready-made dried mixtures have been confirmed by many authors (Alaşalvar, Çam, 2019; Tülek et al., 2020).

The composition of the tea-herbal mixture was obtained by mixing in the claimed ratio of dried and ground ingredients. Dried and crushed components were mixed in the following ratios: Hibiscus sabdariffa - 30\%; Matricaria chamomilla - $20 \%$; Ilex paraguariensis - 10 $\%$; Rosae fructus - $10 \%$; Mentha piperita - $10 \%$; Citrus sinensis - $8 \%$; Citrus limonum $7 \%$; Calendulae flores $-5 \%$. The resulting mixture was brewed in boiling water, kept for several minutes and consumed.

The rational concentration of the components of the mixture was chosen based on the sensory properties of the finished product. The results of sensory evaluation of tea-herbal compositions are shown in Figure 13. The highest score was obtained by tea-herbal composition - S.e. 9,1 points.

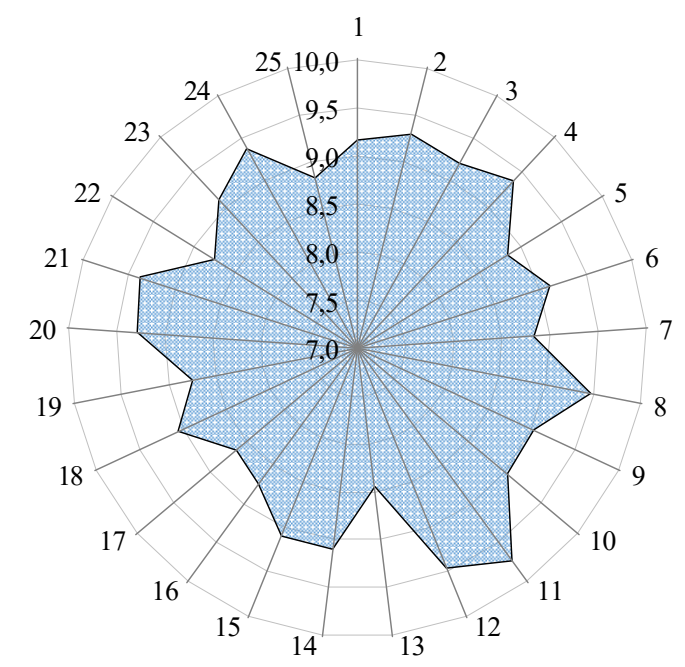

Figure 13. Sensory evaluation of tea-herbal compositions:

1 - color - 9.2 point ( 2 - homogeneous; 3 -red; 4 - pleasant; 5 - pronounced); 6 -infusion - 9.1

point (7-bright; 8 -transparent; 9 - intensive); 10 - taste - 9.0 point $(11$ - pleasant; 12 harmonious; 13 -palpable freshness; 14 -mild; 15 -tart; 16-bitter; 17 -rich; 18 -smell/aroma9.1 point (19-fragrant; 20 -floral; 21 - fresh; 22 - herbal; 23 - pronounced; 24 - pleasant; 24 pleasant; 25 - balanced)

The data obtained are correlated with the basic scientific concepts which are displayed in the works (Abdullah, Mazlan, 2020; Aboagye et al., 2021; Ağagündüz D., 2020; Bekhit et al., 2011; Chan et al., 2010; Gerolis et al., 2017; Gulua et al., 2018; Pérez-Burillo et al., 2018; Silka et al., 2016), regarding the processes of extracting of plant materials.

The developed composition of the tea and herbal mixture ensures the achievement of a synergistic effect, expressed in obtaining a new product with pleasant, harmonious sensory 
properties (Chen et al., 2019; Feng et al., 2019; Guo et al., 2019; Li et al., 2019; Qi et al., 2018; Theuma, Attard, 2020; Xia et al., 2020; Xu et al., 2018; Zeng et al., 2017), high uniformity of distribution of flavoring and biologically active substances (Breiter et al., 2011; Bekhit et al., 2011; Hayat et al., 2015; Spizzirri et al., 2019; Xu et al., 2018).

A functional tea-herbal composition is perfect for everyday consumption, rich in vitamins and microelements, does not contain caffeine and allows you to get a high content of microelements necessary for a person (Aboagye et al., 2021; Guo et al., 2019; Feng et al., 2019; Chen et al., 2019; Hayat et al., 2015).

\section{Conclusions}

Based on the performed theoretical and experimental studies, the following conclusions can be drawn:

1. In the technology of beverages is promising to create tea-herbal compositions, the chemical composition of which includes plants that have bioactive compounds, in particular: catechins, polyphenols, vitamins, carotenoids.

2. Experimental studies show that all aqueous infusions of plant raw materials contain antioxidant systems. It was found that the recovery value of all the tested infusions is positive and ranges from $\left(R E_{\text {inf }}\right)$ in the range from $R E_{\text {inf }}-150.8 \mathrm{mV}$ (Vitis vinifera) to $R E_{\text {inf }}-316.0 \mathrm{mV}$ (Hibiscus sabdariffa).

3. Based on mathematical and statistical analysis, it was found that physicochemical parameters in the range of values with very high correlation $(r$ 0.9-1.0) includes the following indicators: $p H, E h_{\min }, R E_{\text {inf }}, R E_{\text {plant }}$.

4. For the restaurant business in the manufacture of beverages are promising water infusions of Hibiscus sabdariffa and Citrus limonum, which received increased antioxidant characteristics $R E_{\text {inf }}-316.0 \mathrm{mV}$ and $R E_{\text {inf }}-298.0 \mathrm{mV}$, respectively.

5. Rational composition of tea-herbal composition was found: Hibiscus sabdariffa -30 $\%$; Matricaria chamomilla - $20 \%$; Ilex paraguariensis - $10 \%$; Rosae fructus - 10 $\%$; Mentha piperita - $10 \%$; Citrus sinensis - 8\%; Citrus limonum - 7\%; Calendulae flores $-5 \%$.

\section{References}

Abdullah S.S.S., Mazlan A.N. (2020), Quantification of polyphenols and antioxidant activity in several herbal and green tea products in Malaysia, Materials Today: Proceedings, 31(1), pp. A106-A113.

Aboagye G., Tuah B., Bansah E., Tettey C., Hunkpe G. (2021), Comparative evaluation of antioxidant properties of lemongrass and other tea brands, Scientific African, 11, e00718.

Ağagündüz D. (2020), Determination of the total antioxidant and oxidant status of some galactagogue and herbal teas, Food Science and Human Wellness, 9(4), pp. 377-382.

Alaşalvar H., Çam M. (2019), Process for production of ready to drink iced teas from sage (Salvia officinalis L.) and linden (Tilia cordata): pressurized hot water extraction and spray drying, Food Science and Biotechnology, 28(3), pp. 779-785.

Albergaria E.T., Oliveira A.F.M., Albuquerque U.P. (2020), The effect of water deficit stress on the composition of phenolic compounds in medicinal plants, South African Journal of Botany, 131, pp. 12-17.

Andreou V., Strati I.F., Fotakis C., Liouni M., Sinanoglou V.J. (2018), Herbal distillates: A new 
era of grape marc distillates with enriched antioxidant profile, Food Chemistry, 253, pp. 171-178.

Ansari L., Banaei A., Dastranj L., Majdaeen M., Vafapour H., Zamani H., Ataei G., AbediFirouzjah R. (2021), Evaluating the radioprotective effect of single dose and daily oral consumption of green tea, grape seed, and coffee bean extracts against gamma irradiation, Applied Radiation and Isotopes, 174, 109781.

Atefi M., Ghavami A., Hadi A., Askari G. (2021), The effect of barberry (Berberis vulgaris L.) supplementation on blood pressure: A systematic review and meta-analysis of the randomized controlled trials, Complementary Therapies in Medicine, 56, 102608.

Baek Y., Kim H., Mun S., Lee S. (2018), Three-component herbal tea alleviates prolonged fatigue and improves sleep quality: a randomized controlled pilot study, Explore, 14(6), pp. 420-423.

Bag S., Mondal A., Majumder A., Banik A. (2022), Tea and its phytochemicals: Hidden health benefits \& modulation of signaling cascade by phytochemicals, Food Chemistry, 371, 131098.

Banerjee (Roy) R., Bandyopadhyay R., Tudu B., Bhattacharyya N. (2016), Chapter 13 - Tea and the Use of the Electronic Nose, Editor(s): María Luz Rodríguez Méndez, Electronic Noses and Tongues in Food Science, Academic Press, pp. 125-135.

Bekhit A.E.A., Cheng V.J., McConnell M., Zhao J.H., Sedcole R., Harrison R., (2011), Antioxidant activities, sensory and anti-influenza activity of grape skin tea infusion, Food Chemistry, 129(3), pp. 837-845.

Beyzi E., Karaman K., Gunes A., Beyzi S.B. (2017), Change in some biochemical and bioactive properties and essential oil composition of coriander seed (Coriandrum sativum L.) varieties from Turkey, Industrial Crops and Products, 109, pp. 74-78.

Bobrowska-Grzesik E., Jakóbik-Kolon A. (2008), Leaching of cadmium and lead from dried fruits and fruit teas to infusions and decoctions, Journal of Food Composition and Analysis, 21(4), pp. 326-331.

Breiter T., Laue C. Kressel G., Gröll S., Hahn A. (2011), Bioavailability and antioxidant potential of rooibos flavonoids in humans following the consumption of different rooibos formulations, Food Chemistry, 128(215), pp. 338-347.

Chaves P.F.P., Hocayen P.A.S., Dallazen J.L.,. Werner M.F.P, Iacomini M., Andreatini R., Cordeiro L.M.C. (2020), Chamomile tea: Source of a glucuronoxylan with antinociceptive, sedative and anxiolytic-like effects, International Journal of Biological Macromolecules, 164, pp. 1675-1682.

Chan E.W.C., Lim Y.Y., Chong K.L., Tan J.B.L., Wong S.K. (2010), Antioxidant properties of tropical and temperate herbal teas, Journal of Food Composition and Analysis, 23(2), pp. $185-189$.

Chen D., Chen G, Sun Y, Zeng X., Ye H. (2020), Physiological genetics, chemical composition, health benefits and toxicology of tea (Camellia sinensis L.) flower: A review. Food Research International, 137, 109584.

Chen Q., Zhu Y., Dai W., Lv H., Mu B., Li P., Tan J., Ni D., Lin Z. (2019), Aroma formation and dynamic changes during white tea processing, Food Chemistry, 274, pp. 915-924.

Chen L., Mulder P.P.J., Peijnenburg A., Rietjens I.M.C.M. (2019), Risk assessment of intake of pyrrolizidine alkaloids from herbal teas and medicines following realistic exposure scenarios, Food and Chemical Toxicology, 130, pp. 142-153.

Cohen S.M., Eisenbrand G., Fukushima S., Gooderham N.J., Guengerich F.P., Hecht S.S., Rietjens I.M.C.M., Bastaki M., Davidsen J.M., Harman C.L., McGowen M.M., Taylor S.V. (2020), FEMA GRAS assessment of natural flavor complexes: Mint, buchu, dill and caraway derived flavoring ingredients, Food and Chemical Toxicology, 135, 110870.

Coppock R.W., Dziwenka M. (2021), Chapter 41 - Green tea, Editor(s): Gupta R.C., Lall R., Srivastava A. Nutraceuticals. Efficacy, Safety and Toxicity (Second Edition), Academic Press, pp. 697-723. 
Debnath-Canning M., Unruh S., Vyas P., Daneshtalab N., Igamberdiev A.U., Weber J.T. (2020), Fruits and leaves from wild blueberry plants contain diverse polyphenols and decrease neuroinflammatory responses in microglia, Journal of Functional Foods, 68, 103906.

Dell'Aica I., Caniato R., Biggin S., Garbisa S. (2007), Matrix proteases, green tea, and St. John's wort: Biomedical research catches up with folk medicine, Clinica Chimica Acta, 381(1), pp. 69-77.

Długaszek M., Kaszczuk M. (2020), Assessment of the nutritional value of various teas infusions in terms of the macro- and trace elements content, Journal of Trace Elements in Medicine and Biology, 59, 2020, 126428.

Dragan S., Gustavsson L., Streian C., Jupaneant O., Socaciu C., (2012), Comparison of the effects of green tea and hawthorn extracts on endothelial function in isolated human mammary arteries, European Journal of Integrative Medicine, 4(1), p. 170.

Dubey K.K., Janve M., Ray A., Singhal R.S. (2020), Chapter 4 - Ready-to-Drink Tea, Editor(s): Charis M. Galanakis, Trends in Non-alcoholic Beverages, Academic Press, pp. 101-140.

Ertas A., Yener I. (2020), A comprehensive study on chemical and biological profiles of three herbal teas in Anatolia; rosmarinic and chlorogenic acids, South African Journal of Botany, 130, pp. 274-281.

Faienza M.F., Corbo F., Carocci A., Catalano A., Clodoveo M.L., Grano M., Wang D.Q.H., D'Amato G., Muraglia M., Franchini C., Brunetti G., Portincasa P. (2020), Novel insights in health-promoting properties of sweet cherries, Journal of Functional Foods, 69, 103945.

Falcó I., Flores-Meraz P.L., Randazzo W., Sánchez G., López-Rubio A., Fabra M.J. (2019), Antiviral activity of alginate-oleic acid based coatings incorporating green tea extract on strawberries and raspberries, Food Hydrocolloids, 87, pp. 611-618.

Feng Z., Li Y., Li M., Wang Y., Zhang L., Wan X., Yang X. (2019), Tea aroma formation from six model manufacturing processes, Food Chemistry, 285, pp. 347-354.

Frész T., Nagy E., Hilbert Á., Tomcsányi J. (2014), The role of flavonoids in false positive digoxin assays caused by the consumption of hibiscus flower and rose hip tea, International Journal of Cardiology, 171(2), pp. 273-274.

Fu Y., Yang J., Cunningham A.B., Towns A.M., Zhang Y., Yang H., Li J., Yang X., (2018), A billion cups: The diversity, traditional uses, safety issues and potential of Chinese herbal teas, Journal of Ethnopharmacology, 222, pp. 217-228.

Gerolis L.G.L., Lameiras F.S., Krambrock K., Neves M.J. (2017), Effect of gamma radiation on antioxidant capacity of green tea, yerba mate, and chamomile tea as evaluated by different methods, Radiation Physics and Chemistry, 130, pp. 177-185.

Gulua L., Nikolaishvili L., Jgenti M., Turmanidze T., Dzneladze G. (2018), Polyphenol content, anti-lipase and antioxidant activity of teas made in Georgia, Annals of Agrarian Science, 16 (3), pp. 357-361.

Guo X., Ho C.T., Schwab W., Song C., Wan X. (2019), Aroma compositions of large-leaf yellow tea and potential effect of theanine on volatile formation in tea, Food Chemistry, 280, pp. $73-82$.

Halim A.M., Sirajuddin S., Bahar B., Jafar N., Syam A., Masni (2020), The effect of African leaf herbal tea on fast blood glucose on centration of prediabetes teachers in Makassar city, Enfermería Clínica, 30(4), pp. 261-264.

Han N., Gu Y., Ye C., Cao Y., Liu Z., Yin J.(2012), Antithrombotic activity of fractions and components obtained from raspberry leaves (Rubus chingii), Food Chemistry, 132(1), pp. 181-185.

Hayat K., Iqbal H., Malik U., Bilal U., Mushtaq S. (2015), Tea and its consumption: benefits and risks, Critical reviews in food science and nutrition, 55(7), pp. 939-954.

He F., Qian Y.L., Qian M.C. (2018), Flavor and chiral stability of lemon-flavored hard tea during storage, Food Chemistry, 239, pp. 622-630.

Hinkle D.E., Wiersma W., Jurs S.G. (2003), Applied statistics for the behavioral sciences, 


\section{— Food Technology}

Boston, Mass: Houghton Mifflin.

Jeon J.H., Park D., Shin S., Kang D.H., Moon S.H., Kim Y.B. (2007), Effect of green tea and licorice extracts on cyclophosphamide teratogenicity, Reproductive Toxicology, 24(1), p. 75.

Joubert E., Gelderblom W.C.A., Louw A., de Beer D. (2008), South African herbal teas: Aspalathus linearis, Cyclopia spp. and Athrixia phylicoides - A review, Journal of Ethnopharmacology, 119(3), pp. 376-412.

Khan A., Ali S., Murad W., Hayat K., Siraj S., Jawad M., Khan R.A., Uddin J., Al-Harrasi A., Khan A. (2021), Phytochemical and pharmacological uses of medicinal plants to treat cancer: A case study from Khyber Pakhtunkhwa, North Pakistan, Journal of Ethnopharmacology, 281, 114437.

Kuzmin O., Kucherenko V., Sylka I., Isaienko V., Furmanova Y., Pavliuchenko E., Hubenia V. (2020), Antioxidant capacity of alcoholic beverages based on infusions from non-traditional spicy-aromatic vegetable raw materials, Ukrainian Food Journal, 9 (2), pp. 404-424.

Kuzmin O., Kucherenko V., Stukalska N., Kuts A., Oliynyk S., Rakhmetov D. (2020), Antioxidant ability of alcoholic infusions from vegetable raw materials, Ukrainian Food Journal, 9 (4), 795-808.

Li J., Yuan H., Yao Y., Hua J., Yang Y., Dong C., Deng Y., Wang J., Li H., Jiang Y., Zhou Q. (2019), Rapid volatiles fingerprinting by dopant-assisted positive photoionization ion mobility spectrometry for discrimination and characterization of Green Tea aromas, Talanta, 191, pp. 39-45.

Liu Y., Hu R., Shen S., Zhang Z., Zhang J., Song X., Qiang S. (2020), Plant diversity in herbal tea and its traditional knowledge in Qingtian County, Zhejiang Province, China, Plant Diversity, 42(6), pp. 464-472.

Liu P., Kallio H., Yang B., (2014), Flavonol glycosides and other phenolic compounds in buds and leaves of different varieties of black currant (Ribes nigrum L.) and changes during growing season, Food Chemistry, 160, pp. 180-189.

Ma X., Moilanen J., Laaksonen O., Yang W., Tenhu E., Yang B. (2019), Phenolic compounds and antioxidant activities of tea-type infusions processed from sea buckthorn (Hippophaë rhamnoides) leaves, Food Chemistry, 272, pp. 1-11.

Maghsoumi-Norouzabad L., Shishehbor F., Abed R., Javid A.Z., Eftekhar-Sadat B., Alipour B. (2019), Effect of Arctium lappa linne (Burdock) root tea consumption on lipid profile and blood pressure in patients with knee osteoarthritis, Journal of Herbal Medicine, 17-18, 100266.

Małyjurek Z., Zawisza B., de Beer D., Joubert E., Walczak B. (2021), Authentication of honeybush and rooibos herbal teas based on their elemental composition, Food Control, 123, 107757.

Mesquita M., Santos E., Kassuya C.A., Salvador M.J. (2021), Chimarrão, terere and mate-tea in legitimate technology modes of preparation and consume: A comparative study of chemical composition, antioxidant, anti-inflammatory and anti-anxiety properties of the mostly consumed beverages of Ilex paraguariensis St. Hil., Journal of Ethnopharmacology, 279, 114401.

Morré D.M., Morré D.J. (2006), Anticancer activity of grape and grape skin extracts alone and combined with green tea infusions, Cancer Letters, 238(2), pp. 202-209.

Nicolaus C., Junghanns S., Hartmann A., Murillo R., Ganzera M., Merfort I. (2017), In vitro studies to evaluate the wound healing properties of Calendula officinalis extracts, Journal of Ethnopharmacology, 196, pp. 94-103.

Nicoli M.C., Toniolo R., Anese M. (2004), Relationship between redox potential and chainbreaking activity of model systems and foods, Food Chemistry, 88(1), pp. 79-83.

Pavlović T., Dimkić I., Andrić S., Milojković-Opsenica D., Stanković S., Janaćković P., Gavrilović M., Ristivojević P. (2020), Linden tea from Serbia - an insight into the phenolic profile, radical scavenging and antimicrobial activities, Industrial Crops and Products, 154, 
112639.

Peng Y., Tao H., Wang S., Xiao J., Wang Y., Su H. (2021), Dietary intervention with edible medicinal plants and derived products for prevention of Alzheimer's disease: A compendium of time-tested strategy, Journal of Functional Foods, 81, 104463.

Pérez-Burillo S., Giménez R., Rufián-Henares J.A., Pastoriza S. (2018), Effect of brewing time and temperature on antioxidant capacity and phenols of white tea: Relationship with sensory properties, Food Chemistry, 248, pp. 111-118.

Piljac-Žegarac J., Valek L., Stipčević T., Martinez S. (2010), Electrochemical determination of antioxidant capacity of fruit tea infusions, Food Chemistry, 121(3), pp. 820-825.

Podsędek A., Zakłos-Szyda M., Polka D., Sosnowska D. (2020), Effects of Viburnum opulus fruit extracts on adipogenesis of 3T3-L1 cells and lipase activity, Journal of Functional Foods, 73, 104111.

Pohl P., Dzimitrowicz A., Jedryczko D., Szymczycha-Madeja A., Welna M., Jamroz P. (2016), The determination of elements in herbal teas and medicinal plant formulations and their tisanes, Journal of Pharmaceutical and Biomedical Analysis, 130, pp. 326-335.

Prévost H., Brillet-Viel A. (2014), Ecology of bacteria and fungi in foods, Influence of Redox Potential, Encyclopedia of Food Microbiology (Second Edition), pp. 595-601.

Priluckij V.I. (1997), Okislitel'no-vosstanovitel'nyj potencial dlja harakteristiki protivokislitel'noj aktivnosti razlichnyh napitkov $i$ vitaminnyh komponentov, Jelektrohim. aktivacija v medicine, sel. hozjajstve, prom-sti: I Mezhdunar. Simpozium.

Puupponen-Pimiä R., Nohynek L., Juvonen R., Kössö T., Truchado P., Westerlund-Wikström B., Leppänen T., Moilanen E., Oksman-Caldentey K.M. (2016), Fermentation and dry fractionation increase bioactivity of cloudberry (Rubus chamaemorus), Food Chemistry, 197(A), pp. 950-958.

Qi D., Miao A., Cao J., Wang W., Chen W., Pang S., He X., Ma C. (2018), Study on the effects of rapid aging technology on the aroma quality of white tea using GC-MS combined with chemometrics: In comparison with natural aged and fresh white tea, Food Chemistry, 265, pp. 189-199.

Saeed I., Guo X., Azeem M., Elshikh M.S., Zainab B., Ayaz Z., You L., Alwahibi M.S., Abbasi A.M. (2021), Comparative assessment of polyphenolics' content, free radicals' scavenging and cellular antioxidant potential in apricot fruit, Journal of King Saud University - Science, 33(5), 101459.

Salehi B., Selamoglu Z., Şener B., Kılıç M., Jugran A.K., Tommasi N.D., Sinisgalli C., Milella L., Rajkovic J., Morais-Braga M.F., Bezerra C.F., Rocha J.E., Coutinho H.D., Ademiluyi A.O., Shinwari Z.K., Jan S.A., Erol E., Ali Z., Ostrander E.A., Sharifi-Rad J., Cádiz-Gurrea M.D., Taheri Y., Martorell M., Segura-Carretero A., Cho W.C. (2019), Berberis Plants Drifting from Farm to Food Applications, Phytotherapy, and Phytopharmacology, Foods, 8(10), p. 522.

Šavikin K., Zdunić G., Janković T., Gođevac D., Stanojković T., Pljevljakušić D., (2014), Berry fruit teas: Phenolic composition and cytotoxic activity, Food Research International, 62, pp. 677-683.

Shabab S., Gholamnezhad Z., Mahmoudabady M. (2021), Protective effects of medicinal plant against diabetes induced cardiac disorder: A review, Journal of Ethnopharmacology, 265, 113328.

Shendrik T., Levandovskyi L., Kuts A., Prybylskyi V., Karputina M. (2019), Correlation between the quality indicators of activated coal in vodka technology, Ukrainian Journal of Food Science, 7(1), pp. 33-48.

Shonte T.T., Duodu K.G., de Kock H.L. (2020), Effect of drying methods on chemical composition and antioxidant activity of underutilized stinging nettle leaves, Heliyon, 6(5), e03938.

Silka I., Frolova N., Huts V. (2016), Kinetic model of the quality change of modern foodstuffs, 
Food Science and Technology, 10(1), pp. 11-15.

Somasundaram R., Choraria A., George S.M., Narayanaswamy K., Vasudevan K., Antonysamy M., Zhang X., (2019), A preliminary pilot scale analysis of anti-cariogenic activity of green tea powder extract flavoured with Ginger, Cloves and Mint against clinical oral pathogens, Clinical Nutrition Experimental, 24, pp. 66-71.

Spizzirri U.G., Carullo G., De Cicco L., Crispini A., Scarpelli F., Restuccia D., Aiello F. (2019), Synthesis and characterization of a (+)-catechin and L-(+)-ascorbic acid cocrystal as a new functional ingredient for tea drinks, Heliyon, 5(8), e02291.

Sviridonov G.M., Sviridonova L.G., Sviridonov M.G. (2003), Ekologicheskij krizis: kak spastis' i byt' $z$ dorovym, Bijsk, Kedr, $47 \mathrm{~s}$.

Theuma M., Attard E. (2020), From herbal substance to infusion: The fate of polyphenols and trace elements, Journal of Herbal Medicine, 21, 100347.

Tülek Z., Alaşalvar H., Başyiğit B., Berktas S., Salum P., Erbay Z., Telci I., Çam M. (2020), Extraction optimization and microencapsulation of phenolic antioxidant compounds from lemon balm (Melissa officinalis L.): Instant soluble tea production, Journal of Food Processing and Preservation, Available at: https://ifst.onlinelibrary.wiley.com/doi/10.1111/jfpp.14995.

Vidović S., Cvetkovic D., Ramić M., Dunjić M., Malbaša R., Tepić A., Šumić Z., Velićanski A., Jokić S. (2013), Screening of changes in content of health benefit compounds, antioxidant activity and microbiological status of medicinal plants during the production of herbal filter tea, Industrial Crops and Products, 50, pp. 338-345.

Vuong Q.V. (2014), Epidemiological evidence linking tea consumption to human health: a review, Critical reviews in food science and nutrition, 54(4), pp. 523-536.

Xia E., Tong W., Hou Y., An Y., Chen L., Wu Q., Liu Y., Yu J., Li F., Li R., Li P., Zhao H., Ge R., Huang J., Mallano A.I., Zhang Y., Liu S., Deng W., Song C., Zhang Z., Zhao J., Wei S., Zhang Z., Xia T., Wei C., Wan X., (2020), The Reference Genome of Tea Plant and Resequencing of 81 Diverse Accessions Provide Insights into Its Genome Evolution and Adaptation, Molecular Plant, 13(7), pp. 1013-1026.

Xu J., Wang M., Zhao J., Wang Y.H., Tang Q., Khan I.A. (2018), Yellow tea (Camellia sinensis L.), a promising Chinese tea: Processing, chemical constituents and health benefits, Food Research International, 107, pp. 567-577.

Xu C., Liang L., Li Y., YangT., Fan Y., Mao X., Wang Y. (2021), Studies of quality development and major chemical composition of green tea processed from tea with different shoot maturity, $L W T, 142,111055$.

Zhang Y., Wong A.I.C., Wu J., Karim N.B.A., Huang D. (2016), Lepisanthes alata (Malay cherry) leaves are potent inhibitors of starch hydrolases due to proanthocyanidins with high degree of polymerization, Journal of Functional Foods, 25, pp. 568-578.

Zeng L., Zhou Y., Fu X., Mei X., Cheng S., Gui J., Dong F., Tang J., Ma S., Yang Z. (2017), Does oolong tea (Camellia sinensis) made from a combination of leaf and stem smell more aromatic than leaf-only tea? Contribution of the stem to oolong tea aroma, Food Chemistry, 237, pp. 488-498.

Zhu Y., Lv H.P., Dai W.D., Guo L., Tan J.F., Zhang Y., Yu F.L., Shao C.Y., Peng Q.H., Lin Z. (2016), Separation of aroma components in Xihu Longjing tea using simultaneous distillation extraction with comprehensive two-dimensional gas chromatography-time-offlight mass spectrometry, Separation and Purification Technology, 164, pp. 146-154.

Zohurul I.M., Kitamura Y., Kokawa M., Fujii S. (2020), Processing of green tea pastes by micro wet milling system: Influences on physicochemical and functional properties, Innovative Food Science \& Emerging Technologies, 64, 102408. 